\title{
Code Mixing in Health and Hygiene Products Online Advertisements in Indonesia during COVID-19 Pandemic
}

\author{
Ratna Sari Dewi, Rezky Khoirina Tarihoran
}

English Literature Program, Faculty of Letters, Universitas Muslim Nusantara Al Washliyah, Medan, Indonesia.

Corresponding Author: Rezky Khoirina Tarihoran

\begin{abstract}
During the Covid-19 Pandemic, sales figures for health and hygiene products increased sharply. To promote their products, manufacturers take advantage of online media as a promotional medium for reasons of cutting costs and effectiveness. Advertisers employ a variety of creative strategies, including language usage. Certain advertisements incorporate a foreign language, such as English, into the native language. Code mixing is a sociolinguistic study that examines what happens when two languages are mixed in the same sentence in a multilingual society. The purpose of this study was to determine whether code mixing can be used to create advertising appeals in several health and hygiene products online advertisements, which according to Belch include rational and emotional appeals. Throughout the 12 health and hygiene products examined, various forms of code mixing were used as a form of advertising appeal, both rational and emotional. Code mixing can be used deliberately, for example, to attract millennial consumers. However, it could also be coincidental, as there is no equivalent word in Indonesian.
\end{abstract}

Keywords: Code Mixing, Health and Hygiene Products, Online Advertisements.

\section{INTRODUCTION}

The Covid-19 pandemic, which affected nearly every country in the world, including Indonesia, caused widespread panic and devastation in all spheres of life. Additionally, the Indonesian government has implemented a strategy aimed at disrupting the transmission chain of the Covid-19 pandemic. One of them is the implementation of social distancing measures, which require people to perform all tasks at home, including work and education. Clearly, the implementation of this social distancing policy has a significant impact on all spheres of life, particularly the economic sector, indirectly causing economic slowdowns.

However, the Covid-19 Pandemic is not always a source of concern. To improve their health and endurance, people flock to supplement their diets and maintain a clean body and environment. This is demonstrated by the growth in sales of health and hygiene products, particularly via online channels. (Rahman, 2020)

Due to the public's diminished purchasing power as a result of the Covid 19 pandemic, industry activists have had to think more creatively about attracting potential buyers. One of the strategies implemented is to maximize the use of digital advertising or internet advertising, which is considered to be more cost effective and effective at capturing the public's attention. The year 2020 has even been dubbed the "Year of Successful Digital Advertising."

Internet advertising is a type of commercial content created by businesses to educate consumers about a product or service (Schlosser \& S, 1999). Internet advertising can take many forms and be 
distributed via a variety of channels (for example, e-mail messages or interactive games) (e.g. video clips, print or audio). Consumers can make purchases via the internet or other traditional media, As a result, marketing professionals are encouraged to experiment with digital media on the internet in addition to more traditional forms of marketing.

Advertisers employ a variety of creative strategies, including language usage. Advertisements should use language that is as appealing as possible to the intended target audience. Certain advertisements incorporate a foreign language, such as English, into the native language. The use of English in advertising has become a global phenomenon that has spread to numerous countries. Advertisers recognize that using English, beginning with words, sentences, and eventually the entire text, is an effective strategy for selling a brand's product to consumers.

Code mixing is a sociolinguistic study that examines what happens when two languages are mixed in the same sentence in a multilingual society. Additionally, code mixing frequently occurs when a person uses their dominant language but incorporates elements of the second language into their sentences in the form of words or phrases. The desire to describe and interpret, to identify roles, and to identify varieties all contribute to code mixing (Suwito, 1985)

The purpose of this study was to determine whether code mixing can be used to create advertising appeals in several health and hygiene products online advertisements, which according to Belch include rational and emotional appeals.

\section{LITERATURE REVIEW \\ Code Mixing as an Advertising Creative Strategy}

It is critical to pay attention to the creative elements when creating an advertisement. This requires a creative strategy to ensure that the advertisement is not only visually appealing but also appealing to the target audience. There are numerous perspectives on creative advertising. According to the first view, creative advertising can increase product sales. While the second view asserts that advertising is creative when it originates from an original idea and possesses artistic and aesthetic value. Another school of thought maintains that advertising creative is any advertisement that is capable of attracting attention and having an effect on the audience that sees it (Morrisan, 2010)

Advertisers employ a variety of creative strategies, including language usage. Advertisements should use language that is as appealing as possible to the intended target audience. Another frequently used creative strategy is the incorporation of English into the native language. The use of English in advertising is becoming more widespread on a global scale, beginning in various countries. Advertisers recognize that using English, beginning with words, sentences, and eventually the entire text, is an effective strategy for selling a brand's product to consumers. According to Nerghes' research, there are at least three reasons for the phenomenon of the use of the English language in this advertising, namely:

1. Using English as a marketing strategy can result in benefits, cost savings, and consistency of campaigns or slogans, all of which contribute to the creation of a global brand image.

2. The cultural connotations conveyed by English also link the display of values and stereotypes to a more positive effect on consumers. This means that the English language's choice of usage has a greater symbolic value than a communication value. English is thought to be associated with a number of values, including prestige, modernity, globalization, cosmopolitanism, and internationalism.

3. English is used as a linguistic-creative tool to fill in lexical gaps where the appropriate word or expression does not exist in the original language, or 
language words. English may attract consumer attention if it is shorter than the original language or if it is more (Nerghes, 2011)

\section{Advertising Appeals}

The determination of ad appeals is one type of strategy application in creative advertising. This advertising appeal is a term that refers to the strategy used to capture consumers' attention and/or influence their attitudes toward a product (Belch \& Belch, 2001). In general, this advertisement's appeals are divided into two categories: power rationale / information appeal and emotional appeal. Rational appeal emphasizes the product's or brand's characteristics and the benefits associated with a brand product. Complete the advertising message with this appeal, which emphasizes facts, education, and logic (Belch \& Belch, 2001).

According to Belch and Belch, rational appeals can be classified into five categories, including the following:

1. Attribute Appeal (Feature Appeal), which highlights specific characteristics or qualities of a product or service. Advertisements of this type typically provide a wealth of information and highlight a number of critical characteristics that can result in positive consumer attitudes.

2. Competitive Advantages Appeal, which emphasizes certain advantages over comparable products through direct or indirect comparisons.

3. Favorable Price Appeal, which emphasizes the price factor as the advertising message's dominant factor. Typically, this advertisement takes the form of a promotion sale, a special offer, or a bargain at a discounted price.

4. News Appeal, which involves utilizing news or announcements in the mass media regarding the advertised product to garner consumer attention.

5. Popularity Appeal, which emphasizes the use of a number of celebrities or experts who use or recommend the product in question to demonstrate the product's quality (Belch \& Belch, 2001).

Emotional appeals to the consumer's social needs or psychology to purchase products or services. There are two fundamental emotional appeals: those based on personal states or feelings (safety, security, fear, love, affection, self-esteem, actualization, and comfort) and those based on social states or feelings (recognition, status, respect, involvement, rejection, approval).

\section{MATERIALS \& METHODS}

This is a descriptive qualitative study. According to (Ismawati, 2011), qualitative descriptive data is described in words or sentences and then classified to arrive at a conclusion. The study examined digital advertisements for health and hygiene products that appeared in online media. This research focuses on several Code-Mixing citations discovered in these advertisements. The data collection technique used in this study is observation. The researcher is the research instrument. The author uses informal presentation methods to present the results of the data analysis in this research.

\section{RESULTS AND DISCUSSION}

There are 12 examples of online advertisements for health and hygiene products that were used as data in this study, based on the search. These products incorporate both Indonesian and English code mixing in the form of words and phrases.

As stated previously, advertisers use Code Mixing to entice consumers. Belch has identified two types of appeals in advertising, emotional and rational. Belch defines advertising appeals as having two types: rational and emotional appeals. The following will describe how Code Mixing is used to increase the appeal of online advertisements for health and hygiene products: 


\section{Code Mixing used as Rational Appeals}

According to the data gathered, there are some lines from various advertisements that demonstrate the use of code mixing as a rational appeal.

\section{Attribute Appeals}

(a) S.O.S Disinfectant Spray : Dengan Eucalypytus Alami

(b) Nutrimax C+ Plus : Vitamin C dalam bentuk Calcium Ascorbate, bebas asam dan aman bagi lambung

(c) Imboost Effervescent : Generasi Baru Effervescent

(d) Plossa Eucalyptus : Mengandung Eucalyptus Oil dan bahan aktif Cineol yang ampuh sebagai anti virus dan anti bakteri

(e) Spotlight Non Medical Mask : Masker model Duck Bill, Presisi dengan kontur wajah

The data above demonstrates that those lines make the best use of their respective products' strengths. Eucalyptus and Cineol both refer to the primary ingredients in the products they are promoting. The presence of Calcium Ascorbate in the product indicates that it lacks the acidic substance found in other forms of Vitamin C. Meanwhile, the word Effervescent was included in the line to indicate that this product is a more advanced and superior type of effervescent tablet when compared to similar products. Duck Bill is a relatively new term that is gaining popularity in this New Normal era. The advertiser uses the phrase Duck Bill primarily because there is no equivalent in Indonesian.

\section{Competitive Advantage Appeal}

(f) S.O.S Disinfectant Spray: Digunakan untuk Hard \& Soft Surface

Competitive Advantage Appeal is used to demonstrate to potential customers that these products are superior to similar products due to certain features they emphasize. Here, the advertiser wishes to highlight one of his product's advantages, which is that it can be used on both soft and hard surfaces. This demonstrates that comparable products are deficient in these features.

(g) Vitalong $\mathbf{C}$ : Vitamin $\mathrm{C}$ dengan Teknologi Time Release bekerja sepanjang hari

This indicates that only this product that has the Time Release technology. By using this term, the advertiser targets those who are well-educated and more aware of health to understand the meaning of Time Release.

(h) My Baby Extra Thick Wipes: Fresh Fruity Scent Aroma buah yang menyegarkan

The advertiser attempts to emphasize the product's best feature in this advertisement, which is the Fresh Fruity Scent that their other products have.

\section{Favourable Price Appeal}

(i) Guardian Healthy Days : Produk Vitamin \& Suplemen Up To 50\%

(j) Pocari Sweat Ion Water : 6 Botol + Pouch

It's a well-known fact that people adore discounted products and bonuses. The advertisers are clearly attempting to attract customers here by using terms that imply that this advertisement contains a great deal of value. The term Up To means that certain products' prices are reduced by a maximum of $50 \%$, which sounds like a good promotion. Meanwhile, the word Pouch was added to inform potential customers that if they purchase six bottles, they will receive a Pouch as a bonus.

\section{Popularity Appeal}

(k) Septi Wipes \& Septi Air :

Rekomendasi WHO

This product emphasizes its superiority by utilizing the "weapon" of WHO (World Health Organization) recommendations to persuade potential buyers of their products' quality. 


\section{Code Mixing Used as Emotional Appeals}

Several of the advertisements discovered attempted to appeal to the hearts of customers by including English words or phrases.

(l) S.O.S Disinfectant Spray All in One: Bersih OK, Virus KO.

This advertisement cleverly incorporates a word game $(\mathrm{OK}$ and $\mathrm{KO})$ to increase its appeal. However, it is also used to capture the attention of customers. This advertisement claims that this product cleans well (Bersih OK) and effectively removes viruses (virus KO). It wishes to convey to us that if we use this, we will feel secure and will no longer have to worry about viruses.

\section{(m) Sido Muncul Vitamin C 1000 mg:} Cara Fresh Biar Sehat.

This advertisement's tagline translates literally as The Fresh Way to Be Healthy. The term "Fresh" is included to appeal to younger and millennial customers, as Sido Muncul is typically known for producing herbal beverages that are favored by older generations. When we hear the term "Fresh," we immediately envision the pleasure of drinking this product.

(n) Sensodyne Toothpaste: Enjoy tanpa ngilu?

This toothpaste is well-known for those who suffer from sensitive teeth. It's excruciatingly painful for someone with sensitive teeth to attempt to consume sweets or cold beverages, as their teeth immediately react. This advertisement cleverly framed that statement as a question rather than a statement. The line translates literally as "Would you like to enjoy your food and drink without experiencing pain?" It is easy to imagine the pleasure of eating our favourite sweets and cold beverages without having to worry about anything.

\section{CONCLUSION}

Throughout the twelve health and hygiene products examined, various forms of code mixing were used to create rational and emotional appeal in advertising. The Attribute Appeal included the terms Eucalyptus, Calcium Ascorbate, Effervescent, Cineol, and Duck Bill. The Competitive Advantage Appeal was created with a Hard \& Soft Surface, Time Release, and Fresh Fruity Scent. Favourable Price Appeals were used for Up To and Pouch. The WHO (World Health Organization) was cited as a source of popular support. In terms of emotional appeals, terms such as $\mathrm{OK}, \mathrm{KO}$, Fresh, and Enjoy were used to pique the interest of prospective buyers.

Code mixing can be used deliberately to attract millennial consumers, for example. However, it could be coincidental, as Indonesian has no equivalent word.

\section{Acknowledgement: None}

Conflict of Interest: None

\section{Source of Funding: None}

\section{REFERENCES}

1. Belch, G. E., \& Belch, M. A. (2001). Advertising and Promotion: An Integrated Marketing Communications Perspectives (5th ed). New York: Irwin/McGraw Hill.

2. Ismawati, E. (2011). Metode Penelitian Bahasa dan Sastra. Surakarta: Yuma Pustaka.

3. Joseph, G. (2020, 9 30). Dampak COVID-19: Belanja Iklan Digital Naik, Promosi di Primetime Turun. Retrieved from id.techinasia.com: https://id.techinasia.com/dampak-covid19-belanja-iklan

4. Morrisan. (2010). Periklanan: Komunikasi Pemasaran. Jakarta: Kencana.

5. Nerghes, A. (2011). The Impact of Code-Switching. Wageningen: Wageningen University.

6. Rahman, M. R. (2020, 9 19). Pandemi, penjualan produk kesehatan-kecantikan melalui e-commerce naik. Retrieved 
Ratna Sari Dewi et.al. Code mixing in health and hygiene products online advertisements in Indonesia during Covid-19 pandemic.
from
Antaranews.com:
https://www.antaranews.com/berita/173
6025/pandemi-penjualan-produk-
kesehatan-kecantikan-melalui-e- commerce-naik

7. Schlosser, A. E. (1999). Survey of Internet Users' Attitude toward Internet Advertising. Journal of Interactive Marketing, 34-54.
8. Suwito. (1985). Sosiolinguistik:

Pengantar Awal. Surakarta: Henary.

How to cite this article: Dewi RS, Tarihoran

RK. Code mixing in health and hygiene products online advertisements in Indonesia during COVID-19 pandemic. International Journal of Research and Review. 2021; 8(5): 225-230. DOI: https://doi.org/10. 52403/ijrr.20210530

$* * * * * *$ 